\begin{tabular}{|c|c|}
\hline 皮 & $\begin{array}{l}\text { ATRIUM: JURNAL ARSITEKTUR } \\
\text { ISSN: } 2442-7756 \text { e-ISSN: } 2684-6918 \\
\text { atrium.ukdw.ac.id }\end{array}$ \\
\hline
\end{tabular}

\title{
Potensi dan Masalah Destinasi Pariwisata Replika di Daerah Istimewa Yogyakarta
}

Diterima pada 14 April 2021 | Disetujui pada 7 Mei 2021 | Tersedia online 25 Mei 2021 | | DOI: https://doi.org/10.21460/atrium.v7i1.148 |

\section{Amalia Deandra Ristinanda ${ }^{1}$, Wiendu Nuryanti ${ }^{2}$}

1,2. Program Studi Magister Arsitektur, Fakultas Teknik, Universitas Gadjah Mada J1. Grafika No.2, Senolowo, Sinduadi, Kec. Mlati, Kabupaten Sleman, Daerah Istimewa Yogyakarta Email: amaliadeandra@mail.ugm.ac.id

\begin{abstract}
Abstrak
Daerah Istimewa Yogyakarta merupakan aset pariwisata sehingga mempunyai potensi bertumbuhnya destinasi pariwisata. Destinasi pariwisata replika bertumbuh bertolak belakang dengan budaya yang dimiliki oleh daerah dan masyarakatnya. Perlunya melihat kondisi dan perkembangan destinasi pariwisata replika, potensi dan masalahnya serta peluangnya sebagai penggerak distribusi kepariwisataan. Metode yang digunakan dengan wawancara terarah. Hasil secara keseluruhan menyatakan kondisi dan perkembangannya tidak stabil, terdapat lunjakan wisatawan lalu menurun. Melibatkan masyarakat local dan bertambahnya keragaman pariwisata menjadi potensi destinasi ini, namun bermasalah dengan keberlanjutannya. Destinasi pariwisata replika tumbuh karena adanya minat wisatawan dan bermanfaat bagi masyarakat local namun dengan berjalannya waktu mulai ditinggalkan karena bersifat sementara.
\end{abstract}

Kata kunci : destinasi pariwisata replika, destinasi baru, variasi pariwisata

\section{Abstract}

Title: Potential and Problem of Replica Tourism Destinations in Special District of Yogyakarta

Special Region of Yogyakarta is the tourism assets so it has the potential of tourism destinations to grow. The replica tourism destinations grow in contrast to the culture owned by the regions and the community. It is essential to see the condition and the development of the replica tourism destinations, their potentials, their problems and their opportunities as the driving force of tourism distribution. The method used in this research is directive interview. The overall result shown that the condition and the development is unstable, there was a leap of the tourist numbers but then decreasing. The involvement of local community and the increasing of tourism diversity became the potential of these destinations, but they had the problem of being sustainable. The replica tourism destinations grew due to the existence of tourists' interests and they gave benefit to the local community but as time goes by, they were left since they were temporary.

Keywords: replica tourism destination, new destination, variety of tourism 


\section{Pendahuluan}

Salah satu tujuan signifikan dari pengembangan pariwisata adalah adalah membawa keuntungan kepada pemerintah dan investasi industri. Keterkaitan antara kualitas lingkungan yang tinggi dan manfaat ekonomi telah mendapatkan dukungan dalam literatur pariwisata, dalam pengembangan pariwisata perlu memperhatikan lingkungan dan manfaatnya bagi masyarakat. Keseimbangan antara sisi sediaan dengan sisi permintaan adalah kunci keberhasilan dalam pengembangan kepariwisataan yang benar (Gunn, 2002).

Di era modern destinasi pariwisata kian bersaing untuk mendapatkan wisatawan, namun terdapat kesenjangan antara penawaran dan permintaan dalam pariwisata sehingga terciptalah destinasi pariwisata yang tidak memiliki konsep dan tidak sesuai dengan konteks lingkungan. Terbentuklah destinasi pariwisata replika yang menduplikat dan meniru destinasi yang asli tidak berdasarkan kondisi lingkungan, budaya dan masyarakatnya. Perkembangan destinasi pariwisata yang seperti ini akan meredupkan potensi dan identitas asli dan khas yang dimiliki oleh daerah tersebut. Perencanaan pariwisata menciptakan interaksi jangka panjang yang menguntungkan bagi kesejahteraan masyarakat dan keberlanjutan daya dukung lingkungan (Fandeli, 1995).

Daerah Istimewa Yogyakarta memiliki potensi yang dapat menarik wisatawan nusantara maupun wisatawan asing. Destinasi, daya tarik dan atraksi saling berhubungan dan membentuk keharmonisan, keselarasan yang dapat diapresiasi untuk membentuk kualitas destinasi pariwisata (Pendit, 2002). Di Daerah Istimewa Yogyakarta mulai berkembang pesat destinasi pariwisata baru, beberapa destinasi pariwisata memperlihatkan identitas dari Daerah Istimewa Yogyakarta namun beberapa destinasi pariwisata baru justru mereplika dari daerah maupun negara lain yang tidak selaras dengan identitas Daerah Istimewa Yogyakarta yang unik dan khas.

Tumbuhnya destinasi pariwisata yang mereplika dari destinasi pariwisata yang ikonis baik nasional maupun internasional, seperti Menara Eiffel di Paris, Sakura di Jepang, Rumah Hobbit di New Zealand, Stonehenge di Inggris yang merupakan destinasi pariwisata yang terkenal menarik banyak minat wisatawan yang berkunjung. Namun terkendala lokasi yang jauh dan biaya yang mahal maka destinasi pariwisata replika ini merupakan salah satu atraksi yang sangat diminati wisatawan. Daerah Istimewa Yogyakarta memiliki potensi pariwisata yang besar karena memiliki warisan yang asli dan khas, namun pertumbuhan destinasi pariwisata replika ini tidak selaras dengan budaya yang dimiliki oleh daerah dan masyarakatnya. Tujuan penelitian ini yaitu mendiskripsikan potensi dan masalah destinasi pariwisata replika di Daerah Istimewa Yogyakarta.

Destinasi merupakan suatu tempat yang tidak saja menyediakan sesuatu yang dapat dilihat wisatawan, tetapi juga menawarkan aktivitas yang dapat dilakukan oleh wisatawan menjadi daya tarik yang memikat bagi orang untuk berkunjung ke tempat tersebut (Gunn, 1993). Terdapat 4 (empat) komponen pariwisata yang harus dimiliki oleh sebuah objek daya tarik pariwisata, yaitu: atraksi, amenitas, aksesbilitas dan pelayanan tambahan (Cooper, 1995). Kegiatan pariwisata tergantung kepada adanya interaksi antara wisatawan dan 
destinasi pariwisata dan di dukung dengan sarana prasarana pariwisata. Destinasi pariwisata dikatakan menarik apabila banyak dikunjungi wisatawan (Kuntowijoyo, 2006). Pariwisata budaya menjadi salah satu segmen yang memiliki perkembangan yang sangat pesat. Hal ini dilandasi oleh adanya kecenderungan atau tren baru di kalangan wisatawan untuk mencari sesuatu yang unik dan autentik dari suatu kebudayaan (Richards, 1997). Banyaknya wisatawan mancanegara yang mengunjungi sebuah destinasi pariwisata, akan memberikan pengaruh terhadap pengeluaran wisatawan di daerah tujuan wisata tersebut, dikarenakan peningkatan pembelanjaan yang dilakukakan wisatawan akan meningkatan permintaan. (Pitana, 2002).

\section{Kerangka Teori}

Tabel 1. Kerangka teori

\begin{tabular}{|c|c|c|c|}
\hline No & Teori & Tokoh & Tujuan \\
\hline 1 & Potensi pariwisata & (Soekadijo, 2000) & $\begin{array}{lr}\text { Mendeskripsikan } & \text { potensi } \\
\text { perkembangan destinasi } & \text { pariwisata } \\
\text { replika } & \end{array}$ \\
\hline 2 & $\begin{array}{ll}\text { Daya } & \text { tarik } \\
\text { destinasi } & \\
\text { pariwisata } & \\
\end{array}$ & (Yoeti, A. O., 1983) & $\begin{array}{l}\text { Mendeskripsikan } \\
\text { pariwisata replika }\end{array}$ \\
\hline 3 & Keharmonisan & (Pendit, 2002) & $\begin{array}{l}\text { Mendiskripsikan keselarasan destinasi } \\
\text { pariwisata replika }\end{array}$ \\
\hline 4 & Pelayanan & (Cooper, C., 1995) & $\begin{array}{l}\text { Mendiskripsikan pelayanan destinasi } \\
\text { pariwisata replika }\end{array}$ \\
\hline 5 & Hak cipta & UUHC Tahun 2002 & $\begin{array}{l}\text { Mendeskripsikan permasalahan tata } \\
\text { ruang dan hak cipta }\end{array}$ \\
\hline 6 & $\begin{array}{l}\text { Pengoptimalan } \\
\text { pengelolaan }\end{array}$ & (Sunaryo, 2013) & Mendeskripsikan pengelolaan \\
\hline 7 & Peluang & (Pearce, J. A., 2007) & Mendeskripsikan peluang kerja \\
\hline 8 & Kekontrasan & (Pendit, N. S., 2002) & $\begin{array}{l}\text { Mendeskripsikan kekontrasan destinasi } \\
\text { pariwisata }\end{array}$ \\
\hline 9 & Kualitas keamanan & (Innskeep, E., 1987 & Mendeskripsikan keamanan \\
\hline 10 & $\begin{array}{l}\text { Kepuasan } \\
\text { wisatawan }\end{array}$ & (Damanik, et al, 2006) & $\begin{array}{l}\text { Mendeskripsikan kepuasan wisatawan } \\
\text { saat berkunjung }\end{array}$ \\
\hline 11 & $\begin{array}{l}\text { Peningkatan } \\
\text { pembelanjaan }\end{array}$ & (Pitana, 2002) & $\begin{array}{l}\text { Mendeskripsikan dampak peningkatan } \\
\text { pendapatan masyarakat }\end{array}$ \\
\hline 12 & $\begin{array}{l}\text { Kontribusi } \\
\text { Pemerintah pada } \\
\text { kegiatan pariwisata }\end{array}$ & (Nuryanti, W., 1994) & $\begin{array}{l}\text { Mendeskripsikan dampak destinasi } \\
\text { pariwisata replika bagi pemerintah }\end{array}$ \\
\hline 13 & Keuntugan optimal & (Damanik, et al, 2006) & $\begin{array}{l}\text { Mendeskripsikan manfaat destinasi } \\
\text { pariwisata replika }\end{array}$ \\
\hline
\end{tabular}

Sumber: Ristinanda, 2020

\section{Metode}

Metode penelitian pada penelitian ini yaitu kualitatif. Mendeskripsikan kondisi dan perkembangan dari destinasi pariwisata replika di sejumlah kawasan di Daerah Istimewa Yogyakarta. Teknik pengumpulan data yang digunakan yaitu peneliti melakukan wawancara terarah dengan menanyakan pertanyaan kepada informan mengenai hal yang telah 
disiapkan sebelumnya. Metode wawancara dipilih yaitu untuk mendapatkan informasi terkait kondisi dan perkembangan destinasi pariwisata replika. Pengertian wawancara menurut (Subagyo, 2011, p. 39) adalah kegiatan untuk mendapatkan informasi secara langsung kepada informan dengan mengungkapkan pertanyaan dan dilakukan secara lisan. Wawancara adalah teknik pengumpulan data dengan cara tanya jawab yang dilakukan secara langsung antara peneliti dan pihak terkait. Melakukan wawancara untuk mendapatkan sumber informasi kunci yaitu kepada pihak-pihak yang terkait.

Wawancara kepada wisatawan asing dan wisatawan nusantara terkait daya tarik destinasi pariwisata replika, alasan berkunjung, serta pendapat dan saran setelah berkunjung ke destinasi pariwisata replika. Dalam penelitian ini unit analisisnya adalah mengenai potensi dan masalah destinasi pariwisata replika di Daerah Istimewa Yogyakarta. Dilihat dari lima lokasi destinasi pariwisata replika di Daerah Istimewa Yogyakarta yaitu The World Landmark - Merapi Park Yogyakarta. The Lost World Castle, Hobbit House Merapi, Taman Hobit Mangunan, Stonehenge Yogyakarta.

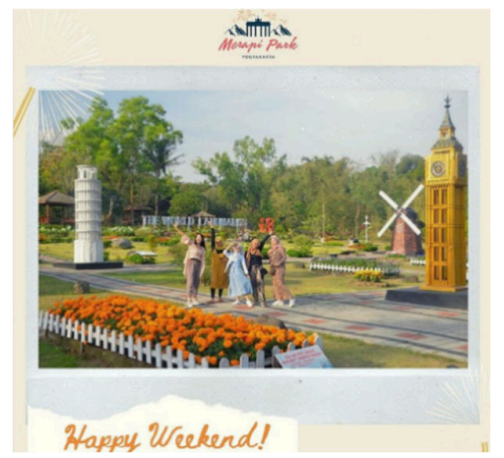

Gambar 1. The World Landmark Merapi Sumber:

https://www.instagram.com/p/CCwv2sWJslz/? utm_source=ig_web_copy_link, diakses Mei 2021

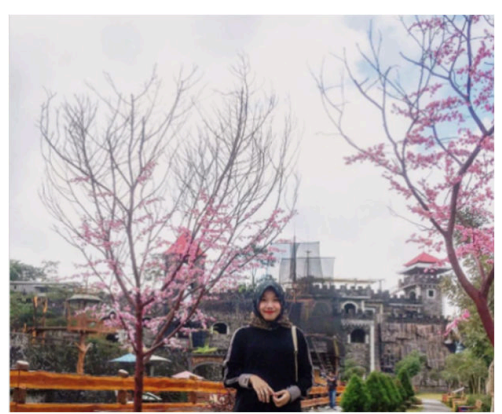

Gambar 2. The Lost World Castle Sumber:

https://www.instagram.com/p/CNlniG4hAXC/ ?utm_source=ig_web_copy_link, diakses Mei 2021

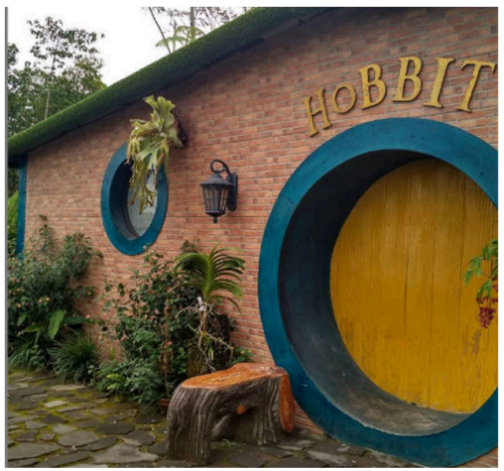

Gambar 3. Hobbit House Merapi Sumber: https://www.instagram.com/p/BgxfqaIAD4G/? utm_source=ig_web_copy_link, diakses Mei 2021

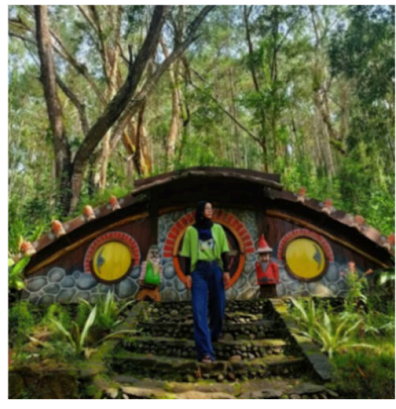

Gambar 4. Taman Hobbit Mangunan Sumber :

https://www.instagram.com/p/CMRiuqmAUTI/ ?utm_source=ig_web_copy_link, diakses Mei 2021 


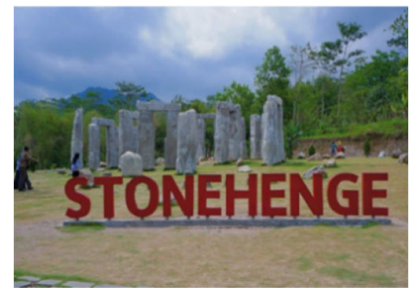

Gambar.5. Stonehenge Yogyakarta Sumber:

https://www.instagram.com/p/BrB4IVqAV_J/? utm_source=ig_web_copy_link, diakses Mei 2021

Teknik analisis data yaitu mengikuti model analisis Miles dan Huberman (Huberman, 1992) yaitu, reduksi data (penyaringan/pemilahaan data), penyajian data (display data), verifikasi data (pengujian kebenaran data)

\section{Hasil dan Pembahasan}

Potensi Destinasi Pariwisata Replika Destinasi pariwisata replika memiliki sumber daya yang menjadi faktor penarik wisatawan. Tersedianya faktor penarik dan pendorong yang menjadikan destinasi pariwisata replika memiliki potensi sebagai variasi destinasi pariwisata. Sebagai variasi destinasi pariwisata, destinasi pariwisata replika memiliki daya tarik yang menarik minat wisatawan dengan berbagai atraksi yang di tawarkan.

Destinasi pariwisata baru ini merupakan destinasi yang menawarkan pengalaman baru yang sedang tren saat ini. Pengalaman baru ini menambah variasi pariwisata di Daerah Istimewa Yogyakarta.

Sebagai variasi destinasi pariwisata, destinasi pariwisata replika ini memiliki potensi bertumbuh dan berkembang di Daerah Istimewa Yogyakarta. Meningkatnya wisatawan yang berkunjung dan keberadaannya mulai menjamur menjadi alasan destinasi ini masih bertahan, namun daya tariknya kurang cocok berada di Daerah Istimewa Yogyakarta.

Potensi destinasi pariwisata replika memiliki atraksi yang mengundang rasa ingin tahu dan penasaran wisatawan. Destinasi ini memiliki potensi keberadaannya di Daerah Istimewa Yogyakarta karena adanya wisatawan yang berkunjung sehingga memiliki potensi untuk berkembang namun daya tarik atraksinya perlu diperhatikan karena mengalami penurunan kunjungan wisatawan.

Tabel 2. Matriks potensi destinasi pariwisata replika

\begin{tabular}{|c|c|c|c|c|c|c|}
\hline \multicolumn{7}{|c|}{ Potensi Destinasi Pariwisata Replika } \\
\hline \multirow[t]{2}{*}{ No. } & \multirow[t]{2}{*}{ Parameter } & \multicolumn{5}{|c|}{$\begin{array}{ll}\text { Lokasi } \\
\end{array}$} \\
\hline & & $\begin{array}{l}\text { The World } \\
\text { Landmark } \\
\text { Merapi }\end{array}$ & $\begin{array}{l}\text { The Lost } \\
\text { World } \\
\text { Castle }\end{array}$ & $\begin{array}{l}\text { Hobbit } \\
\text { House } \\
\text { Merapi }\end{array}$ & $\begin{array}{l}\text { Taman Hobbit } \\
\text { Mangunan }\end{array}$ & $\begin{array}{l}\text { Stonehenge } \\
\text { Yogyakarta }\end{array}$ \\
\hline 1 & $\begin{array}{l}\text { Potensi destinasi } \\
\text { pariwisata replika }\end{array}$ & $\begin{array}{l}\text { Memiliki } \\
\text { atraksi yang } \\
\text { sedang tren } \\
\text { dan } \\
\text { instagram- } \\
\text { able }\end{array}$ & $\begin{array}{l}\text { Mengun- } \\
\text { dang rasa } \\
\text { ingin tahu } \\
\text { dan } \\
\text { penasaran }\end{array}$ & $\begin{array}{l}\text { Menawar- } \\
\text { kan spot } \\
\text { yang } \\
\text { instagram } \\
\text {-able }\end{array}$ & $\begin{array}{l}\text { Banyaknya } \\
\text { orang yang } \\
\text { penasaran } \\
\text { menyebabkan } \\
\text { destinasi } \\
\text { pariwisata } \\
\text { replika ini } \\
\text { menjadi tren }\end{array}$ & $\begin{array}{l}\text { Digemari } \\
\text { wisatawan } \\
\text { yang } \\
\text { penasaran } \\
\text { dengan } \\
\text { destinasi ini }\end{array}$ \\
\hline 2 & $\begin{array}{l}\text { Potensi } \\
\text { perkembangan di } \\
\text { DIY }\end{array}$ & $\begin{array}{l}\text { Adanya } \\
\text { peningkatan } \\
\text { wisatawan } \\
\text { yang } \\
\text { berkunjung } \\
\end{array}$ & $\begin{array}{l}\text { Destinasi } \\
\text { replika } \\
\text { sudah } \\
\text { banyak } \\
\text { dijumpai }\end{array}$ & $\begin{array}{l}\text { Memiliki } \\
\text { kunjungan } \\
\text { wisatawan } \\
\text { yang } \\
\text { tinggi } \\
\end{array}$ & $\begin{array}{l}\text { Memiliki } \\
\text { potensi } \\
\text { berkembang } \\
\text { meskipun } \\
\text { perlu melihat }\end{array}$ & $\begin{array}{l}\text { Memiliki } \\
\text { potensi } \\
\text { berkembang } \\
\text { sebagai objek } \\
\text { penyangga }\end{array}$ \\
\hline
\end{tabular}




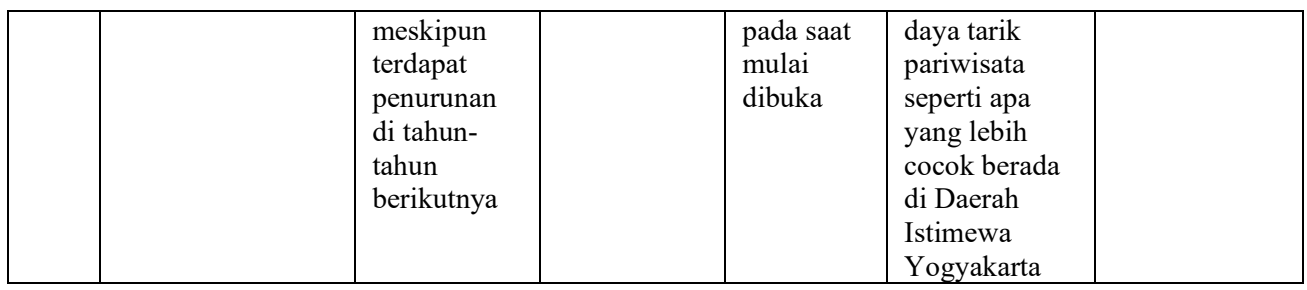

Sumber: Hasil analisis, 2020

The World Landmark memiliki potensi sebagai destinasi pariwisata karena memiliki atraksi yang sedang trend dan instagramable. Memiliki peningkatan pengunjung meskipun terdapat penurunan di tahun-tahun berikutnya. Potensi yang dimiliki destinasi pariwisata replika The Lost World Castle berasal dari atraksi yang ditawarkan mengundang rasa ingin tau dan penasaran wisatawan. Karena sudah mulai banyak dijumpai di berbagai lokasi dengan objek yang serupa maka potensi perkembangan destinasi ini di Daerah Istimewa Yogyakarta mulai menurun.

Market merupakan faktor-faktor yang mempengaruhi wisatawan melakukan perjalanan wisata, adanya minat wisatawan maka Hobbit House Merapi memiliki potensi untuk berkembang.
Potensi yang dimiliki Hobbit House Merapi yaitu dengan menawarkan spot yang instagramable dan berpotensi berkembang di DIY karena memiliki kunjungan wisatawan yang tinggi pada saat mulai dibuka meskipun setiap tahunnya menurun. Banyaknya orang yang penasaran menyebabkan destinasi pariwisata replika ini menjadi tren merupakan potensi Taman Hobbit Mangunan. Memiliki potensi berkembang tetapi perlu melihat daya tarik pariwisata seperti apa yang lebih cocok berada di Daerah Istimewa Yogyakarta sehingga ada keberlanjutan. Potensi yang dimiliki destinasi pariwisata replika Stonehenge Yogyakarta digemari oleh wisatawan yang penasaran dengan destinasi ini dan memiliki potensi berkembang sebagai objek penyangga pariwisata di Daerah Istimewa Yogyakarta.

Tabel 3. Matriks prosentase potensi destinasi pariwisata replika

\begin{tabular}{|c|c|c|c|c|c|c|}
\hline No. & Parameter & $\begin{array}{c}\text { The World } \\
\text { Landmark } \\
\text { Merapi (\%) }\end{array}$ & $\begin{array}{c}\text { The Lost } \\
\text { World } \\
\text { Castle (\%) }\end{array}$ & $\begin{array}{c}\text { Hobbit } \\
\text { House } \\
\text { Merapi (\%) }\end{array}$ & $\begin{array}{c}\text { Taman } \\
\text { Hobbit } \\
\text { Mangunan } \\
\text { (\%) }\end{array}$ & $\begin{array}{c}\text { Stonehenge } \\
\text { Yogyakarta } \\
\text { (\%) }\end{array}$ \\
\hline 1 & $\begin{array}{c}\text { Potensi } \\
\text { destinasi } \\
\text { pariwisata } \\
\text { replika }\end{array}$ & 60 & 75 & 80 & 60 & 100 \\
\hline $\begin{array}{c}\text { Potensi } \\
\text { perkembangan } \\
\text { di DIY }\end{array}$ & 66 & 67 & 66 & 75 & 67 \\
\hline \multicolumn{2}{|c|}{ TOTAL } & $63.00 \%$ & $71 \%$ & $73.00 \%$ & $67.50 \%$ & $83.50 \%$ \\
\hline
\end{tabular}

Sumber: Hasil analisis, 2020

Destinasi pariwisata replika Stonehenge Yogyakarta memiliki prosentase tertinggi dalam potensi destinasi pariwisata replika dalam perannya sebagai variasi destinasi pariwisata karena memiliki potensi berkembang 
sebagai objek penyangga. Dalam potensi perkembangan di DIY Taman Hobbit Mangunan memiliki prosentase yang paling tinggi, karena destinasi ini yang dalam perkembangannya bekerja sama dengan berbagai pihak dan mengikutsertakan masyarakat lokal.

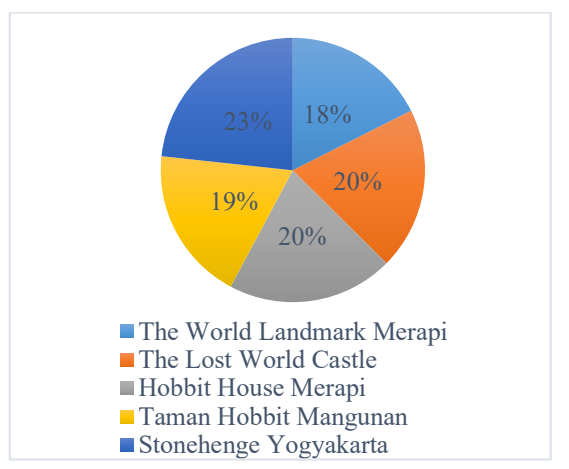

\section{Gambar 6. Grafik prosentase potensi destinasi pariwisata replika Sumber: Hasil analisis, 2020}

Grafik di atas menunjukan prosentase potensi dari destinasi pariwisata replika. Dilihat dari grafiknya, Stonehenge Yogyakarta merupakan destinasi pariwisata replika yang paling berpotensi sebagai variasi destinasi pariwisata karena destinasi ini hanya ada satu di Yogyakarta sehingga menarik dan berpotensi mengundang wisatawan. Selanjutnya Hobbit House Merapi juga berpotensi sebagai variasi destinasi pariwisata dengan spot-spot yang instagramable. The Lost World Castle merupakan destinasi pariwisata replika yang memiki potensi sebagai objek penyangga. Selanjutnya Taman Hobbit Mangunan cukup berpotensi juga karena memiliki daya tarik yang sedang tren. The World Landmark Merapi cukup berpotensi dengan atraksi yang menarik dan instagramable.

\section{Masalah Destinasi Pariwisata Replika}

Unik dan Autentik merupakan unsur yang tidak dapat ditemui di tempat lain.
Budaya merupakan image Daerah Istimewa Yogyakarta. Keharmonisan destinasi pariwisata replika dengan Daerah Istimewa Yogyakarta merupakan salah satu hal yang pro dan kontra karena tidak selaras dengan image Daerah Istimewa Yogyakarta. Suasana alam di Daerah Istimewa Yogyakarta sangat menarik untuk dikunjungi, lokasi destinasi pariwisata replika yang berdekatan dengan alam dan memanfaatkan potensi alam menjadi daya tarik baru bagi wisatawan.

Terdapat tiga destinasi pariwisata replika beberapa destinasi pariwisata replika melakukan pelanggaran RTRW yaitu The Lost World Castle, Hobbit House Merapi dan Stonehenge Yogyakarta. Taman Hobit Mangunan dan The World Landmark Merapi tidak melanggar RTRW karena lokasi yang digunakan sudah mendapat ijin membangun dan sesuai ketentuan. Taman Hobit Mangunan memanfaatkan Tanah milik Kementerian Lingkungan Hidup dan Kehutanan sedangkan The World Landmark Merapi menggunakan tanah khas desa.

Undang-Undang Hak Cipta (UUHC) merupakan hukum nasional, sedangkan destinasi ikonik dunia ini berada di luar negeri. Penerapan hukum internasional tidak sesederhana penerapan hukum nasional. Karena sebagian dari subjek hukum internasional berada dalam wilayah hukum nasional, di mana subjek hukum internasional itu berada. Suatu negara tentu memiliki hukum nasional tersendiri yang berlaku di masing-masing negara dan belum tentu selalu sejalan dengan hukum internasional. Selama Indonesia tidak meratifikasi atau menyetujui perjanjian Internasional maka hukum internasional tidak berlaku di Indonesia. Bertumbuh dan berkembangnya destinasi pariwisata replika di Indonesia 
menunjukan bahwa belum ada peraturan yang mengikat melalui perjanjian Internasional. Setiap cagar budaya yang masuk dalam UNESCO memiliki OUV (Outstanding Universal Value) yang tidak mudah di tiru serupa dengan aslinya. Walaupun terdapat perlindungan mengenai Hak Cipta, destinasi pariwisata replika dapat dikatakan tidak melanggar aturan hak cipta karena bangunan yang ditiru tidak identik dengan wujud aslinya dan belum ada peraturan yang mengikat. Namun secara tidak langsung destinasi pariwisata replika menawarkan dan mempromosikan bangunan ikonik yang merupakan produk pariwisata negara lain yang bukan merupakan produk daerah.

Destinasi pariwisata replika ini merupakan destinasi tiruan yang bertolak belakang dengan destinasi yang asli dan berbasis budaya di Daerah Istimewa Yogyakarta, destinasi pariwisata replika ini bukanlah produk asli daerah namun menjadi produk daerah karena berdampak bagi warga sekitar.

Produk berbalut budaya memiliki nilai yang khas dan memiliki daya tarik yang berbeda dari daerah satu dengan lainnya. Pariwisata yang berbasis citra budaya menggambarkan keunikan yang dimiliki Daerah Istimewa Yogyakarta. Destinasi pariwisata replika kontras dengan identitas budaya Daerah Istimewa Yogyakarta karena hanya mengutamakan tren saat ini tanpa melihat keselarasannya.

Kualitas destinasi pariwisata selain dilihat dari sisi komponen pariwisatanya, juga penting untuk melihat keamanan bagi wisatawan yang berkunjung. Dengan memperhatikan keamanan maka destinasi pariwisata replika aman untuk dikunjungi. Selain faktor keamanan, kepuasan wisatawan dalam berkunjung dinilai dapat menjadi faktor yang mendukung. Rata - rata wisatawan yang berkunjung cukup puas mengunjungi destinasi pariwisata replika karena bisa mencoba pengalaman baru dengan melihat destinasi pariwisata yang tidak monoton sebagai wisata swafoto.

Destinasi ini merupakan destinasi yang sedang tren sehingga wisatawan cukup puas saat mengunjungi dan berwisata menuju destinasi pariwisata replika ini dengan teman dan keluarga.Destinasi ini merupakan destinasi pariwisata yang dapat diandalkan untuk saat ini karena menjadi sumber penghasilan bagi warga yang tinggal di sekitar destinasi pariwisata replika ini, dengan perkembangan destinasi ini warga mendapatkan dampak peningkatan pendapatan walaupun tidak semua secara signifikan.

Selain dapat diandalkan, destinasi pariwisata replika memiliki dampak positif karena merupakan sumber pendapatan dan ladang pekerjaan bagi masyarakat sehingga masyarakat merasakan secara langsung keuntungan dari keberadaan destinasi pariwisata replika. Meskipun destinasi pariwisata replika ini berdampak positif bagi masyarakat, keberlanjutan destinasi pariwisata ini perlu diperhatikan. Dengan melakukan inovasi maka keberadaan destinasi ini akan lebih bermanfaat untuk kedepannya dan tidak hanya bersifat sementara selama destinasi pariwisata replika ini masih merupakan tren wisata.

Destinasi pariwisata replika tidak memiliki keselarasan dengan Daerah Istimewa Yogyakarta karena tidak adanya identitas dan sentuhan khas. Pelayanan destinasi ini baik. Dalam peraturan RTRW beberapa destinasi 
pariwisata replika melanggar. destinasi pariwisata replika dapat dikatakan tidak melanggar aturan hak cipta karena bangunan yang ditiru tidak identik dengan wujud aslinya dan belum ada peraturan yang mengikat. Pengelolaan dan kepemilikian destinasi ini memiliki perbedaan rata-rata dikelola oleh warga local namun beberapa destinasi pariwisata replika dikelola oleh individu. Mayoritas destinasi ini memang diciptakan untuk membantu masyarakat sekitar sebagai peluang kerja. Destinasi ini kontras dengan budaya dan lingkungannya. Destinasi ini aman bagi pengunjung karena adanya pengawasan dan memenuhi standart keamanan. Wisatawan juga cukup puas saat mengunjungi destinasi ini karena menawarkan spot foto yang menarik. Destinasi ini meningkatkan pendapatan bagi masyarakat sekitar karena dikelola oleh warga. Sehingga destinasi pariwisata replika ini bermanfaat sebagai lapangan kerja bagi masyarakat sekitar.

Tabel 4. Matrik masalah destinasi pariwisata replika

\begin{tabular}{|c|c|c|c|c|c|c|}
\hline \multicolumn{7}{|c|}{ Potensi Destinasi Pariwisata Replika } \\
\hline \multirow{2}{*}{ No. } & \multirow{2}{*}{ Parameter } & \multicolumn{5}{|c|}{$\begin{array}{ll} & \text { Lokasi } \\
\end{array}$} \\
\hline & & $\begin{array}{l}\text { The World } \\
\text { Landmark } \\
\text { Merapi }\end{array}$ & $\begin{array}{l}\text { The Lost } \\
\text { World Castle }\end{array}$ & $\begin{array}{l}\text { Hobbit } \\
\text { House } \\
\text { Merapi }\end{array}$ & $\begin{array}{l}\text { Taman } \\
\text { Hobbit } \\
\text { Mangunan }\end{array}$ & $\begin{array}{l}\text { Stonehenge } \\
\text { Yogyakarta }\end{array}$ \\
\hline 1 & $\begin{array}{l}\text { Keselarasan } \\
\text { dengan DIY }\end{array}$ & $\begin{array}{l}\text { Tidak } \\
\text { memiliki } \\
\text { sentuhan } \\
\text { khas Daerah } \\
\text { Istimewa } \\
\text { Yogyakarta }\end{array}$ & $\begin{array}{l}\text { Tidak selaras } \\
\text { karena tidak } \\
\text { ada sentuhan } \\
\text { khas Daerah } \\
\text { Istimewa } \\
\text { Yogyakarta }\end{array}$ & $\begin{array}{l}\text { Tidak } \\
\text { selaras } \\
\text { karena tidak } \\
\text { ada identitas } \\
\text { yang } \\
\text { menunjukan } \\
\text { daerah } \\
\text { tempat } \\
\text { destinasi } \\
\text { pariwisata } \\
\text { replika ini } \\
\text { berada yaitu } \\
\text { di Daerah } \\
\text { Istimewa } \\
\text { Yogyakarta }\end{array}$ & $\begin{array}{l}\text { Meskipun } \\
\text { menyatu } \\
\text { dengan alam } \\
\text { destinasi } \\
\text { pariwisata ini } \\
\text { tidak } \\
\text { memperlihatk } \\
\text { an kekhasan } \\
\text { daerah }\end{array}$ & $\begin{array}{l}\text { Tidak } \\
\text { menyatu } \\
\text { dengan lokasi } \\
\text { tempatnya } \\
\text { berdiri yaitu } \\
\text { Daerah } \\
\text { Istimewa } \\
\text { Yogyakarta } \\
\text { yang kaya } \\
\text { akan budaya }\end{array}$ \\
\hline 2 & Pelayanan & $\begin{array}{l}\text { Memiliki } \\
\text { pelayanan } \\
\text { yang baik } \\
\text { sehingga } \\
\text { wisatawan } \\
\text { merasakan } \\
\text { kenyamanan } \\
\text { saat } \\
\text { berkunjung } \\
\end{array}$ & $\begin{array}{l}\text { Cukup baik } \\
\text { dengan } \\
\text { adanya } \\
\text { pengarahan } \\
\text { terhadap } \\
\text { wisatawan }\end{array}$ & $\begin{array}{l}\text { Cukup baik } \\
\text { namun } \\
\text { minimnya } \\
\text { jumlah } \\
\text { petugas } \\
\text { yang } \\
\text { melayani } \\
\text { wisatawan }\end{array}$ & $\begin{array}{l}\text { Pelayanan } \\
\text { yang cukup } \\
\text { baik yang } \\
\text { membuat } \\
\text { wisatawan } \\
\text { merasa } \\
\text { nyaman saat } \\
\text { berkunjung }\end{array}$ & $\begin{array}{l}\text { Pelayanan } \\
\text { yang baik } \\
\text { dengan } \\
\text { adanya } \\
\text { pengarahan } \\
\text { dari petugas }\end{array}$ \\
\hline 3 & $\begin{array}{l}\text { RTRW dan } \\
\text { Hak Cipta }\end{array}$ & $\begin{array}{l}\text { Tidak } \\
\text { melanggar } \\
\text { RTRW dan } \\
\text { aturan Hak } \\
\text { Cipta }\end{array}$ & $\begin{array}{l}\text { Melanggar } \\
\text { RTRW tapi } \\
\text { tidak } \\
\text { melanggar } \\
\text { aturan Hak } \\
\text { Cipta }\end{array}$ & $\begin{array}{l}\text { Melanggar } \\
\text { RTRW tapi } \\
\text { tidak } \\
\text { melanggar } \\
\text { aturan Hak } \\
\text { Cipta }\end{array}$ & $\begin{array}{l}\text { Tidak } \\
\text { melanggar } \\
\text { RTRW dan } \\
\text { aturan Hak } \\
\text { Cipta }\end{array}$ & $\begin{array}{l}\text { Melanggar } \\
\text { RTRW tapi } \\
\text { tidak } \\
\text { melanggar } \\
\text { aturan Hak } \\
\text { Cipta }\end{array}$ \\
\hline 4 & Pengelolaan & $\begin{array}{l}\text { Dikelola oleh } \\
\text { Individu }\end{array}$ & $\begin{array}{l}\text { Dikelola oleh } \\
\text { warga sekitar } \\
\text { (local) }\end{array}$ & $\begin{array}{l}\text { Dikelola } \\
\text { oleh warga } \\
\text { sekitar } \\
\text { (local) }\end{array}$ & $\begin{array}{l}\text { Dikelola oleh } \\
\text { Kesatuan } \\
\text { Pengelolaan } \\
\text { Hutan } \\
\text { Yogyakarta } \\
\text { dan }\end{array}$ & $\begin{array}{l}\text { Dikelola oleh } \\
\text { warga sekitar } \\
\text { (local) }\end{array}$ \\
\hline
\end{tabular}


Ristinanda, Potensi dan Masalah Destinasi Pariwisata Replika...

\begin{tabular}{|c|c|c|c|c|c|c|}
\hline & & & & & $\begin{array}{l}\text { Kelompok } \\
\text { Tani Hutan }\end{array}$ & \\
\hline 5 & Peluang kerja & $\begin{array}{l}\text { Menciptakan } \\
\text { peluang kerja } \\
\text { bagi } \\
\text { masyarakat } \\
\text { namun dalam } \\
\text { pengelolaann } \\
\text { ya pemilik } \\
\text { yang paling } \\
\text { berwenang }\end{array}$ & $\begin{array}{l}\text { Masyarakat } \\
\text { sendiri yang } \\
\text { menciptakan } \\
\text { destinasi ini }\end{array}$ & $\begin{array}{l}\text { Masyarakat } \\
\text { sendiri yang } \\
\text { mencipta- } \\
\text { kan } \\
\text { destinasi ini }\end{array}$ & $\begin{array}{l}\text { Meningkatkan } \\
\text { peluang } \\
\text { pekerjaan bagi } \\
\text { masyarakat } \\
\text { karena yang } \\
\text { dulunya hanya } \\
\text { petani }\end{array}$ & $\begin{array}{l}\text { Masyarakat } \\
\text { sendiri yang } \\
\text { menciptakan } \\
\text { destinasi ini }\end{array}$ \\
\hline 6 & $\begin{array}{l}\text { Kekontrasan } \\
\text { Destinasi } \\
\text { pariwisata }\end{array}$ & $\begin{array}{l}\text { Kontras } \\
\text { dengan } \\
\text { budaya } \\
\text { Yogyakarta }\end{array}$ & $\begin{array}{l}\text { Tidak } \\
\text { menggambar- } \\
\text { kan identitas } \\
\text { budaya } \\
\text { Yogyakarta }\end{array}$ & $\begin{array}{l}\text { Memiliki } \\
\text { konsep yang } \\
\text { kontras } \\
\text { dengan } \\
\text { budaya }\end{array}$ & $\begin{array}{l}\text { Kontras } \\
\text { dengan } \\
\text { lingkungan } \\
\text { dan } \\
\text { budayanya } \\
\text { karena tidak } \\
\text { ada unsur } \\
\text { budaya }\end{array}$ & $\begin{array}{l}\text { Tidak ada } \\
\text { keselarasan } \\
\text { antara lokasi } \\
\text { dan konsep } \\
\text { dari } \\
\text { Stonehenge } \\
\text { Yogyakarta }\end{array}$ \\
\hline 7 & Keamanan & $\begin{array}{l}\text { Keamanan- } \\
\text { nya terjamin }\end{array}$ & $\begin{array}{l}\text { Sudah aman } \\
\text { karena adanya } \\
\text { pengawasan } \\
\text { dari petugas, } \\
\text { namun ada } \\
\text { beberapa titik } \\
\text { yang kurang } \\
\text { aman }\end{array}$ & $\begin{array}{l}\text { Adanya } \\
\text { pengawasan } \\
\text { dan aman } \\
\text { digunakan } \\
\text { bagi anak- } \\
\text { anak }\end{array}$ & $\begin{array}{l}\text { Keamanan } \\
\text { yang sudah } \\
\text { dirancang } \\
\text { sebelumnya } \\
\text { oleh pihak } \\
\text { pengelola } \\
\text { menyebabkan } \\
\text { destinasi } \\
\text { pariwisata } \\
\text { replika ini } \\
\text { aman bagi } \\
\text { wisatawan } \\
\end{array}$ & $\begin{array}{l}\text { Memiliki } \\
\text { atraksi yang } \\
\text { aman bagi } \\
\text { orang dewasa } \\
\text { maupun anak- } \\
\text { anak dan } \\
\text { petugas } \\
\text { mengawasi } \\
\text { dengan baik }\end{array}$ \\
\hline 8 & Kepuasan & $\begin{array}{l}\text { Cukup } \\
\text { memuaskan } \\
\text { bagi } \\
\text { wisatawan } \\
\text { karena } \\
\text { destinasi ini } \\
\text { menawarkan } \\
\text { banyak spot } \\
\text { foto yang } \\
\text { tidak } \\
\text { monoton }\end{array}$ & $\begin{array}{l}\text { Spot foto yang } \\
\text { unik sehingga } \\
\text { cukup } \\
\text { memuaskan } \\
\text { bagi } \\
\text { wisatawan } \\
\text { yang } \\
\text { berkunjung }\end{array}$ & $\begin{array}{l}\text { Cukup } \\
\text { memuaskan } \\
\text { bagi } \\
\text { wisatawan } \\
\text { karena } \\
\text { menyedia- } \\
\text { kan } \\
\text { beberapa } \\
\text { spot foto } \\
\text { sebagai } \\
\text { atraksi } \\
\text { wisata } \\
\end{array}$ & $\begin{array}{l}\text { Cukup } \\
\text { memuaskan } \\
\text { karena dapat } \\
\text { menikmati } \\
\text { berswafoto } \\
\text { bersama di } \\
\text { destinasi } \\
\text { pariwisata } \\
\text { yang sedang } \\
\text { tren }\end{array}$ & $\begin{array}{l}\text { Memuaskan } \\
\text { bagi } \\
\text { pengunjung } \\
\text { karena dapat } \\
\text { berswafoto } \\
\text { bersama } \\
\text { dengan } \\
\text { keluarga }\end{array}$ \\
\hline 9 & $\begin{array}{l}\text { Dampak } \\
\text { Peningkatan } \\
\text { pendapatan } \\
\text { masyarakat }\end{array}$ & $\begin{array}{l}\text { Kurang } \\
\text { merasakan } \\
\text { peningkatan } \\
\text { pendapatan } \\
\text { dikarenakan } \\
\text { destinasi } \\
\text { pariwisata } \\
\text { replika ini } \\
\text { dimiliki dan } \\
\text { dikelola oleh } \\
\text { individu }\end{array}$ & $\begin{array}{l}\text { Peningkatan } \\
\text { pendapatan } \\
\text { didapatkan } \\
\text { dari } \\
\text { pengelolaan } \\
\text { yang } \\
\text { dilakukan } \\
\text { oleh warga }\end{array}$ & $\begin{array}{l}\text { Peningkatan } \\
\text { pendapatan } \\
\text { didapatkan } \\
\text { dari } \\
\text { pengelolaan } \\
\text { yang } \\
\text { dilakukan } \\
\text { oleh warga }\end{array}$ & $\begin{array}{l}\text { Peningkatan } \\
\text { pendapatan } \\
\text { didapatkan } \\
\text { dari } \\
\text { pengelolaan } \\
\text { yang } \\
\text { dilakukan } \\
\text { oleh warga }\end{array}$ & $\begin{array}{l}\text { Peningkatan } \\
\text { pendapatan } \\
\text { didapatkan } \\
\text { dari } \\
\text { pengelolaan } \\
\text { yang } \\
\text { dilakukan } \\
\text { oleh warga }\end{array}$ \\
\hline 10 & $\begin{array}{l}\text { Dampak } \\
\text { destinasi } \\
\text { pariwisata } \\
\text { replika bagi } \\
\text { pemerintah }\end{array}$ & $\begin{array}{l}\text { Dampak } \\
\text { positif } \\
\text { namun } \\
\text { belum ada } \\
\text { pencapaian } \\
\text { program } \\
\text { yang disusun } \\
\text { bersama } \\
\text { dengan } \\
\text { pemerintah }\end{array}$ & $\begin{array}{l}\text { Dampak } \\
\text { positif karena } \\
\text { merupakan } \\
\text { sumber } \\
\text { pendapatan } \\
\text { dan ladang } \\
\text { pekerjaan bagi } \\
\text { masyarakat } \\
\text { sekitarnya }\end{array}$ & $\begin{array}{l}\text { Dampak } \\
\text { positif } \\
\text { karena } \\
\text { merupakan } \\
\text { sumber } \\
\text { pendapatan } \\
\text { dan ladang } \\
\text { pekerjaan } \\
\text { bagi }\end{array}$ & $\begin{array}{l}\text { Dampak } \\
\text { positif karena } \\
\text { merupakan } \\
\text { sumber } \\
\text { pendapatan } \\
\text { dan ladang } \\
\text { pekerjaan bagi } \\
\text { masyarakat } \\
\text { sekitarnya }\end{array}$ & $\begin{array}{l}\text { Dampak } \\
\text { positif karena } \\
\text { merupakan } \\
\text { sumber } \\
\text { pendapatan } \\
\text { dan ladang } \\
\text { pekerjaan } \\
\text { bagi } \\
\text { masyarakat } \\
\text { sekitarnya } \\
\end{array}$ \\
\hline
\end{tabular}




\begin{tabular}{|l|l|l|l|l|l|l|}
\hline & & $\begin{array}{l}\text { untuk } \\
\text { perencanaan } \\
\text { dan } \\
\text { perkembang- } \\
\text { an destinasi } \\
\text { pariwisata } \\
\text { replika }\end{array}$ & $\begin{array}{l}\text { masyarakat } \\
\text { sekitarnya }\end{array}$ & & \\
\hline 11 & $\begin{array}{l}\text { Manfaat } \\
\text { destinasi } \\
\text { pariwisata } \\
\text { replika }\end{array}$ & $\begin{array}{l}\text { Tidak } \\
\text { sepenuhnya } \\
\text { bermanfaat } \\
\text { bagi } \\
\text { masyarakat } \\
\text { terutama } \\
\text { destinasi } \\
\text { yang dimiliki } \\
\text { oleh individu }\end{array}$ & $\begin{array}{l}\text { Menjadi } \\
\text { lapangan kerja } \\
\text { bagi } \\
\text { masyarakat }\end{array}$ & $\begin{array}{l}\text { Menjadi } \\
\text { lapangan } \\
\text { kerja bagi } \\
\text { masyarakat }\end{array}$ & $\begin{array}{l}\text { Menjadi } \\
\text { lapangan kerja } \\
\text { bagi } \\
\text { masyarakat }\end{array}$ & $\begin{array}{l}\text { Menjadi } \\
\text { lapangan } \\
\text { kerja bagi } \\
\text { masyarakat }\end{array}$ \\
\hline
\end{tabular}

Sumber: Hasil analisis, 2020

Masalah destinasi pariwisata replika The World Landmark Merapi yaitu keselarasan dan kekontrasannya. The World Landmark tidak memiliki sentuhan khas Daerah Istimewa Yogyakarta. Kualitas destinasi pariwisata yang meberikan kenyamanan bagi wisatawan, pelayanan destinasi ini baik. Destinasi pariwisata replika dapat dikatakan tidak melanggar aturan hak cipta karena bangunan yang ditiru tidak identik dengan wujud aslinya dan belum ada peraturan yang mengikat. The World Landmark Merapi tidak melanggar RTRW karena lokasi yang digunakan sudah mendapat ijin menggunakan tanah khas desa. The World Landmark Merapi dikelola oleh individu namun dalam pengelolaannya pemilik yang paling berwenang. Destinasi pariwisata replika ini bukanlah produk asli daerah namun kontras dengan budaya Yogyakarta. Dengan memperhatikan keamanan maka destinasi pariwisata replika aman untuk dikunjungi. Dari sisi kepuasan, wisatawan cukup memuaskan bagi wisatawan karena destinasi ini menawarkan banyak spot foto yang tidak monoton. Masyarakat disekitar The World Landmark Merapi kurang merasakan peningkatan pendapatan dikarenakan destinasi pariwisata replika ini dimiliki dan dikelola oleh individu.
Terdapat dampak positif namun belum ada pencapaian program yang disusun bersama dengan pemerintah untuk perencanaan dan perkembangan destinasi pariwisata replika.

Permasalahan destinasi The Lost World Castle yaitu keselarasan dimana destinasi ini tidak selaras karena tidak ada sentuhan khas Daerah Istimewa Yogyakarta namun karena sedang tren sehingga destinasi pariwisata replika memiliki potensi untuk mengembangkan pariwisata. Pelayanan yang baik akan mempengaruhi potensi destinasi ini, pelayanannya cukup baik dengan adanya pengarahan terhadap wisatawan yang berkunjung. Destinasi pariwisata replika dapat dikatakan tidak melanggar aturan hak cipta karena bangunan yang ditiru tidak identik dengan wujud aslinya dan belum ada peraturan yang mengikat namun melanggar RTRW karena terbangun di lokasi merupakan KLB 3 dimana tidak boleh ada aktivitas permanen. Destinasi dikelola oleh warga sekitar (local) sehingga masyarakat sendiri yang menciptakan destinasi ini. Meskipun warga sendiri yang menciptakan namun The Lost World Castle tidak menggambarkan identitas budaya Yogyakarta. Penting untuk melihat keamanan bagi wisatawan yang berkunjung, destinasi ini sudah aman 
karena adanya pengawasan dari petugas, namun beberapa titik masih belum sesuai standart keamanan seperti pagar pembatas. Dengan adanya spot foto yang unik sehingga The Lost World Castle cukup memuaskan bagi wisatawan yang berkunjung. Pengelolaan destinasi ini dilakukan oleh warga sehingga menjadi sumber pendapatan dan ladang pekerjaan bagi masyarakat sekitarnya.

Keselarasan destinasi pariwisata replika dengan Daerah Istimewa Yogyakarta merupakan hal yang penting. Namun Hobbit House Merapi tidak selaras karena tidak ada identitas yang menunjukan daerah tempat destinasi pariwisata replika ini berada yaitu di Daerah Istimewa Yogyakarta. Meskipun pelayanan cukup baik namun jumlah petugas yang melayani wisatawan sangat minim. Destinasi pariwisata replika dapat dikatakan tidak melanggar aturan hak cipta karena bangunan yang ditiru tidak identik dengan wujud aslinya dan belum ada peraturan yang mengikat namun melanggar RTRW karena terbangun di lokasi merupakan KLB 3 dimana tidak boleh ada aktivitas permanen. Hobbit House Merapi dikelola oleh warga sekitar dimana masyarakat sendiri yang menciptakan destinasi ini. Destinasi pariwisata replika ini bukanlah produk asli daerah memiliki konsep yang kontras dengan budaya namun menjadi produk daerah karena berdampak bagi warga sekitar. Namun Hobbit House Merapi keamanannya terjamin karena adanya pengawasan dan aman digunakan bagi anak-anak dan cukup memuaskan bagi wisatawan karena menyediakan beberapa spot foto sebagai atraksi wisata. Karena masyarakat sendiri yang menciptakan destinasi ini maka adanya peningkatan pendapatan. Bagi pemerintah dengan adanya Hobbit House Merapi memberikan dampak positif dan bermanfaat sebagai sumber pendapatan dan ladang pekerjaan bagi masyarakat sekitarnya.

Meskipun menyatu dengan alam destinasi pariwisata ini tidak selaras karena tidak memperlihatkan kekhasan daerah. Pelayanannya yang baik maka akan mempengaruhi keinginan wisatawan untuk berkunjung kembali dan membuat wisatawan merasa nyaman saat berkunjung. Destinasi pariwisata replika dapat dikatakan tidak melanggar aturan hak cipta karena bangunan yang ditiru tidak identik dengan wujud aslinya dan belum ada peraturan yang mengikat. Taman Hobbit Mangunan tidak melanggar RTRW karena diijinkan untuk memanfaatkan Tanah milik Kementerian Lingkungan Hidup dan Kehutanan. Taman Hobbit Mangunan dikelola oleh Kesatuan Pengelolaan Hutan Yogyakarta dan Kelompok Tani Hutan sehingga meningkatkan peluang pekerjaan bagi masyarakat karena yang dulunya hanya petani. Taman Hobbit Mangunan memiliki konsep yang kontras dengan lingkungan dan budayanya karena tidak ada unsur budaya namun menjadi produk daerah karena berdampak bagi warga sekitar. Dengan keamanan yang sudah dirancang sebelumnya oleh pihak pengelola menyebabkan Taman Hobbit Mangunan aman bagi wisatawan. Destinasi ini cukup memuaskan karena dapat menikmati berswafoto bersama di destinasi pariwisata yang sedang tren. Karena masyarakat sendiri yang menciptakan destinasi ini maka terjadi peningkatan pendapatan. Bagi pemerintah Taman Hobbit Mangunan memberikan dampak positif dan bermanfaat karena merupakan sumber 
pendapatan dan ladang pekerjaan bagi masyarakat sekitarnya.

Stonehenge Yogyakarta tidak menyatu dengan lokasi tempatnya berdiri yaitu Daerah Istimewa Yogyakarta yang kaya akan budaya sehingga tidak selaras dengan Daerah Istimewa Yogyakarta. Pelayanannya baik dengan adanya pengarahan dari petugas. Destinasi pariwisata replika dapat dikatakan tidak melanggar aturan hak cipta karena bangunan yang ditiru tidak identik dengan wujud aslinya dan belum ada peraturan yang mengikat namun melanggar RTRW karena terbangun di lokasi merupakan KLB 3 dimana tidak boleh ada aktivitas permanen. Stonehenge Yogyakarta dikelola oleh warga sekitar jadi masyarakat sendiri yang menciptakan destinasi ini. Stonehenge Yogyakarta tidak memiliki keselarasan antara lokasi dan konsep atraksi yang ditawarkan. Meskipun kontras Stonehenge Yogyakarta memiliki atraksi yang aman bagi orang dewasa maupun anak-anak dengan adanya petugas mengawasi dengan baik. Destinasi ini cukup memuaskan karena dapat berswafoto bersama dengan keluarga. Karena masyarakat sendiri yang menciptakan destinasi ini maka terdapat pendapatan masyarakat meningkat dari pengelolaan yang dilakukan oleh warga. Bagi pemerintah, Stonehenge Yogyakarta memiliki dampak positif karena dapat bermanfaat dan menjadi sumber pendapatan dan ladang pekerjaan bagi masyarakat.

Tabel 5. Matrik prosentase masalah destinasi pariwisata replika

\begin{tabular}{|c|l|c|c|c|c|c|}
\hline No & \multicolumn{1}{|c|}{ Parameter } & $\begin{array}{c}\text { The World } \\
\text { Landmark } \\
\text { Merapi (\%) }\end{array}$ & $\begin{array}{c}\text { The Lost } \\
\text { World } \\
\text { Castle (\%) }\end{array}$ & $\begin{array}{c}\text { Hobbit } \\
\text { House } \\
\text { Merapi (\%) }\end{array}$ & $\begin{array}{c}\text { Taman } \\
\text { Hobbit } \\
\text { Mangunan } \\
(\%)\end{array}$ & $\begin{array}{c}\text { Stonehenge } \\
\text { Yogyakarta } \\
\text { (\%) }\end{array}$ \\
\hline 1 & $\begin{array}{l}\text { Keselarasan } \\
\text { dengan DIY }\end{array}$ & 80 & 100 & 40 & 60 \\
\hline 2 & Pelayanan & 40 & 40 & 20 & 20 & 20 \\
\hline 3 & $\begin{array}{l}\text { RTRW dan Hak } \\
\text { Cipta }\end{array}$ & 0 & 50 & 50 & 0 & 50 \\
\hline 4 & Pengelolaan & 50 & 20 & 20 & 20 & 20 \\
\hline 5 & Peluang kerja & 0 & 0 & 0 & 0 & 0 \\
\hline 6 & $\begin{array}{l}\text { Kekontrasan } \\
\text { Destinasi } \\
\text { pariwisata }\end{array}$ & 100 & 67 & 67 & 75 & 0 \\
\hline 7 & Keamanan & 20 & 40 & 0 & 20 & 0 \\
\hline 8 & Kepuasan & 0 & 0 & 20 & 0 & 0 \\
\hline 9 & $\begin{array}{l}\text { Dampak } \\
\text { Peningkatan } \\
\text { pendapatan } \\
\text { masyarakat }\end{array}$ & 20 & 0 & 0 & & 0 \\
\hline 10 & $\begin{array}{l}\text { Dampak destinasi } \\
\text { pariwisata replika } \\
\text { bagi pemerintah }\end{array}$ & 20 & 0 & 0 & 0 & 0 \\
\hline 11 & $\begin{array}{l}\text { Manfaat destinasi } \\
\text { pariwisata replika }\end{array}$ & 20 & 0 & 0 & 0 & 0 \\
\hline TOTAL & $31.80 \%$ & $27 \%$ & $25.20 \%$ & $17.70 \%$ & $19.70 \%$ \\
\hline
\end{tabular}

Sumber: Hasil analisis, 2020

Dari sisi keselarasan Hobbit House Merapi merupakan destinasi yang paling tidak selaras karena tidak ada identitas yang menunjukan daerah tempat destinasi pariwisata. Sedangkan dalam pelayanannya The World Landmark Merapi dan The Lost World Castle memiliki pelayanan yang kurang 
dibandingkan destinasi pariwisata replika lainnya.

Dalam peraturan RTRW The Lost World Castle, Hobbit House Merapi dan Stonehenge Yogyakarta melanggar karena berada di area KLB 3. Sedangkan dalam UUHC destinasi pariwisata replika ini tidak melanggar karena belum ada peraturan yang mengikat. Dari sisi pengelolaan The World Landmark Merapi kurang melibatkan masyarakat local untuk berpartisipasi dalam pengelolaannya. Namun rata-rata seluruh destinasi pariwisata replika memberikan peluang pekerjaan bagi masyarakat lokal.

Destinasi pariwisata replika kontras dengan budaya, terutama The World Landmark Merapi yang seharusnya mencerminkan karakter wilayah Sleman Utara. Sedangkan dari segi keamanannya The Lost World Castle perlu memperhatikan beberapa titik masih belum sesuai standart keamanan. Dari kepuasan wisatawan, wisatawan yang berkunjung ke Hobbit House Merapi dan Taman Hobbit Mangunan belum cukup puas karena atraksi yang ditawarkan dalam kondisi fisik yang kurang baik dan membutuhkan perawatan.

Dalam upaya memberikan lapangan pekerjaan, The World Landmark Merapi belum memerikan dampak yang cukup besar dalam peningkatan pendapatan masyarakat. The World Landmark Merapi juga belum memberikan dampak bagi pemerintah dalam pencapaian program yang disusun bersama dengan pemerintah untuk perencanaan dan perkembangan destinasi ini.

Keberadaan destinasi pariwisata replika cukup memberikan manfaat baik bagi pemerintah, masyarakat lokal dan wisatawan. Namun dibandingkan destinasi lainnya, karena dikelola oleh inidividu menjadikan The World Landmark Merapi tidak sepenuhnya memberikan manfaat.

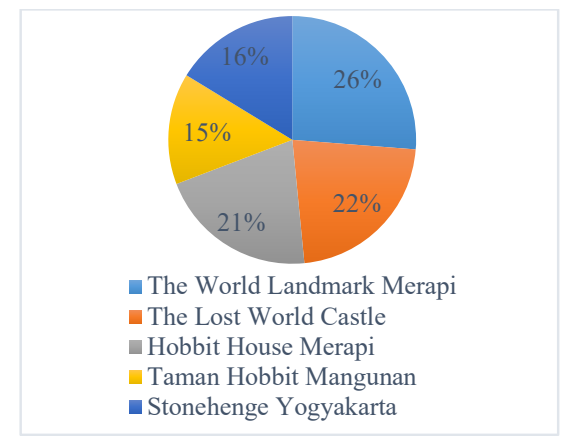

\section{Gambar 7. Grafik prosentase masalah destinasi pariwisata replika Sumber: Hasil analisis, 2020}

Melihat dari grafik masalah destinasi pariwisata replika, maka destinasi dengan tingkat permasalahan tertinggi adalah The World Landmark Merapi memiliki masalah pada keselarasan dan kekontrasan terhadap Daerah Istimewa Yogyakarta. Selain itu destinasi ini belum melakukan pencapaian program yang disusun bersama dengan pemerintah. Masyarakat disekitar The World Landmark Merapi juga kurang ikut berpartisipasi dalam destinasi ini.

Disusul oleh The Lost World Castle tidak selaras dengan lingkungannya karena tidak adanya asentuhan khas daerah. Permasalahan selanjutnya adalah mengenai lokasi yang dibangun di area yang berpotensi membahayakan bagi wisatawan. Selain itu perlu memperhatikan beberapa titik yang kurang aman bagi wisatawan.

Selanjutnya Hobbit House Merapi tidak selaras karena tidak ada identitas yang menunjukan daerah tempat destinasi pariwisata replika ini berada yaitu di Daerah Istimewa Yogyakarta. Destinasi ini juga terbangun di area yang 
berbahaya bagi keselamatan wisatawan. Stonehenge Yogyakarta tidak menyatu dengan lokasi tempat destinasi ini dibangun dan terlihat sangat kontras. Selain itu destinasi ini melanggar RTRW yang dapat tidak diperbolehkan melakukan aktivitas permanen.

Destinasi yang memiliki tingkat masalah terendah yaitu Taman Hobbit Mangunan, meskipun destinasi ini kontras dengan lokasinya berada namun tidak melakukan pelanggaran. Selain itu destinasi ini juga dikelola oleh Kesatuan Pengelolaan Hutan Yogyakarta dan Kelompok Tani Hutan sehingga meningkatkan peluang pekerjaan bagi masyarakat.

\section{Kesimpulan dan Saran}

Pariwisata sangat dinamis dan terus berubah untuk memenuhi selera dan keinginan pasar baru. Terciptalah destinasi pariwisata replika yang memiliki karakter seperti berikut yaitu, destinasi pariwisata replika sangat populer di kalangan wisatawan nusantara namun tidak berlaku bagi wisatawan asing karena destinasi pariwisata replika ini meniru bangunan ikonik yang berasal dari daerah asalnya. Destinasi pariwisata replika cepat populer karena citra bangunan ikonik ini dikenal oleh masyarakat luas sebelumnya seperti Menara Eiffel di Paris, Big Ben di London yang sangat popular untuk dikunjungi wisatawan. Dengan daya tarik baru dan mudah dikenali oleh masyarakat luas menjadikan destinasi pariwisata replika ini mudah dipromosikan dengan menawarkan sensasi berada di luar negeri dengan harga yang ekonomis. Destinasi pariwisata replika memiliki waktu atau durasi popularitas yang pendek sehingga apabila tidak diimbangi dengan inovasi produk secara menerus maka destinasi pariwisata ini tidak memiliki keberlanjutan. Destinasi pariwisata replika melibatkan masyarakat local sebagai pengelola maupun pengurus destinasi ini sehingga membawa dampak positif bagi masyarakatnya. Potensi masalah yang timbul karena berkembangnya destinasi pariwisata replika yaitu dalam hal hak cipta. Sampai saat ini belum banyak informasi yang didapatkan dalam penelitian ini, namun karena hal ini penting sehingga menjadi area masalah yang perlu diteliti lebih lanjut. Termasuk di dalam hal ini kaitannya dengan UUHC. Terkait dengan sebaran destinasi pariwisata replika, terdapat indikasi-indikasi yang mengarah pada pelanggaran terhadap peraturan dan ketentuan-ketentuan tata ruang yaitu berada di kawasan KLB (Kejadian Luar Bisa) 3 yang sewaktu-waktu dapat membahayakan pengunjung. Hal ini disebabkan karena destinasi pariwisata replika dikembangkan secara instan dan sering kali tidak disertai dengan perencanaan yang matang. Sebagai pemanfaatan peluang dan penggerak distribusi kunjungan, destinasi pariwisata replika cenderung dikembangkan dengan meniru apa adanya dari yang aslinya dengan inovasi yang terbatas. Hal ini menyebabkan rendahnya kunjungan ulang (repeaters).

Potensi yang ada pada destinasi pariwisata replika ini yaitu menawarkan pengalaman baru bagi wisatawan menjadi potensi yang dimiliki destinasi pariwisata replika. Pengalaman mengunjungi bangunan ikonis dunia tanpa mengunjungi tempat aslinya merupakan potensi destinasi ini karena pengalaman baru menjadikan destinasi pariwisata replika menjadi tren wisata. Dapat menjadi identitas suatu wilayah dengan cepat dan menggerakan kunjungan wisatawan dengan cepat. 
Keberadannya sebagai sumber pendapatan dan ladang pekerjaan masyarakat lokal merupakan peluang bagi destinasi pariwisata replika untuk bertumbuh.

Masalah yang dihadapi oleh destinasi pariwisata replika ini yaitu dikarenakan destinasi ini berada di Daerah Istimewa Yogyakarta. Lokasi tempat destinasi ini dibangun memiliki potensi pariwisata yang besar serta memiliki warisan yang asli dan khas, sedangkan pertumbuhan destinasi pariwisata replika ini tidak selaras dengan budaya yang dimiliki oleh daerah dan masyarakatnya dengan konsep yang bertolak belakang dengan citra kawasan. Wisatawan yang berkunjung berpendapat bahwa destinasi ini tidak selaras dengan image Yogyakarta dilihat dari unsur budaya yang kental dan berbeda dari kota lainnya, kota Yogyakarta sangat istimewa dengan berbagai destinasi pariwisata yang berbalut citra kawasan. Tidak adanya sentuhan khas Yogyakarta merupakan alasan dominan dari wisatawan yang melihat ketidak selarasan keberadaan destinasi pariwisata replika ini. Destinasi ini mengutamakan tren yang bersifat sementara.

Rekomendasi untuk pembuat kebijakan (policy makers) sebagai berikut, yaitu pengaturan amenitas yang memadai sehingga menyangga kebutuhan pariwisata, pengaturan safety security yang terjamin di destinasi pariwisata replika agar keamanan wisatawan terjaga dan penguatan citra daerah terhadap masyarakat dan perencana sebagai inovasi pengembangan destinasi pariwisata.

Rekomendasi untuk perencana maupun perancang pariwisata yaitu pengaturan tata ruang dan tata guna lahan yang sesuai peruntukannya yang menjadi prioritas perencana sebelum merencanakan suatu destinasi pariwisata, perancangan destinasi pariwisata replika yang memiliki ekspresi arsitektur yang baik sehingga bisa dipertanggungjawabkan dengan destinasi aslinya. Perlu adanya inovasiinovasi baru dalam desain replika yang tidak hanya mencontoh apa adanya namun juga lebih mengembangkan lebih lanjut secara kreatif.

Rekomendasi bagi penelitian lebih lanjut adalah untuk mengetahui segmen pasar yang tertarik dengan destinasi pariwisata replika karena di berbagai wilayah Indonesia destinasi pariwisata replika ini mulai tumbuh menjamur dengan cepat. Juga, penelitian mengenai inovasi desain yang bisa dikembangkan dari ikon-ikon destinasi pariwisata dunia sehingga wisata yang terbentuk tidak hanya mencontoh persis dari aslinya.

\section{Ucapan Terima Kasih}

Puji Syukur kepada Tuhan atas terselesainya penelitian ini. Ucapan terima kasih kepada suami dan keluarga. Kepada Dewan Redaksi ATRIUM: Jurnal Arsitektur serta Fakultas Teknik Arsitektur UGM dan kepada seluruh pihak yang memberi kontribusi dalam penelitian ini.

\section{Daftar Pustaka}

Cooper, C. (1995). Tourism, principles and practice. Harlow: Prentice Hall.

Damanik, J. \& Weber, H. F. (2006). Perencanaan ekowisata dari teori ke aplikasi. Yogyakarta: CV.Andi Offset. 
Fandeli, C. (1995). Dasar-Dasar manajemen kepariwisataan alam. Yogyakarta: Lliberty.

Gunn, C. A. (1993). Tourism planning basic, concepts, cases. Washington DC: Taylor and Francis.

Gunn, C. A. (2002). Tourism planning : basics, concepts, cases, 4th edition. New York: Routledge.

Huberman, M. M. (1992). Analisis data kualitatif. Jakarta: UI Press.

Innskeep, E. (1987). Environmental planning for tourism. Annals of Tourism Reaserch, 14, 118-135.

Kuntowijoyo. (2006). Budaya dan masyarakat. Yogyakarta: Tiara Wacana.

Nuryanti, W. (1994). Perencanaan pembangunan regional dan kawasan untuk kepariwisataan alam. Makalah disampaikan pada diklat peningkatan mutu profesionalisme pengelola obyek dan daya tarik pariwisata, 1994. Tidak dipublikasikan.

Pearce, J. A. (2007). Manajemen Strategik : Formulasi, Implementasi dan Pengendalian. Jakarta: Penerbit Salemba Empat.

Pendit, N. S. (2002). Ilmu pariwisata : sebuah pengantar perdana. Jakarta: Pradnya Paramita.

Pitana, I. (2002). Pariwisata, wahana pelestarian kebudayaan dan dinamika. Bali: Universitas Udayana.

Republik Indonesia. (2002). UndangUndang Nomor 19 Tahun 2002 tentang Hak Cipta (Lembaran Negara Republik Indonesia Tahun 2002 Nomor 85, Tambahan Lembaran Negara Republik Indonesia Nomor 4220). Jakarta: Lembaran Negara R.I.
Richards, G. (1997). Cultural tourism in europe. Wallingford: $\mathrm{CAB}$ INTERNATIONAL.

Soekadijo, R. G. (2000). Anatomi pariwisata. Jakarta: Penerbit PT Gramedia.

Subagyo, P. (2011). Metodologi penelitian dalam teori dan praktek. Jakarta: Aneka Cipta.

Sunaryo, B. (2013). Kebijakan pembangunan destinasi pariwisata : konsep dan aplikasinya di indonesia. Yogyakarta: Gava Media.

Yoeti, A. O. (1983). Pengantar ilmu pariwisata. Bandung: Angkasa. 